\title{
Dampak Covid-19 terhadap Pergerakan Nilai Tukar Rupiah dan Indeks Harga Saham Gabungan (IHSG)
}

\author{
Haryanto ${ }^{1}$ \\ Kementerian Perencanaan Pembangunan Nasional/Bappenas Republik Indonesia
}

\begin{abstract}
Studi ini meneliti dampak Covid-19 terhadap nilai tukar (Indonesia Rupiah terhadap Dollar AS) dan Indeks Harga Saham Gabungan (IHSG) di Indonesia. Penelitian ini menggunakan data harian kasus Covid-19, nilai tukar dan periode CSPI dari 2 Maret hingga 30 April 2020. Hasil analisis menunjukkan: (1) peningkatan 1\% pada kasus Covid-19 menyebabkan depresiasi sebesar Rupiah terhadap Dollar AS sebesar 0,02\%, (2) peningkatan 1\% dalam kasus Covid-19, menyebabkan koreksi ke CSPI sebesar 0,03\%, (3) peningkatan 1\% dari CSPI mengarah ke apresiasi Rupiah terhadap Dollar AS sebesar 0,311\% . Dengan demikian, Covid19 berdampak pada depresiasi Rupiah terhadap Dollar AS, dan berdampak menurun pada CSPI, sehingga diperlukan intervensi kebijakan untuk mengendalikan penyebaran wabah Covid-19, mengendalikan kepanikan agar tidak berdampak pada Rupiah dan pasar saham melalui berbagai kebijakan stimulus.
\end{abstract}

Kata Kunci: dampak covid-19; IHSG; nilai tukar rupiah

${ }^{1}$ Haryanto adalah Perencana Ahli Utama di Kedeputian Bidang Ekonomi Kementerian Perencanaan Pembangunan Nasional/Bappenas RI. Email: haryanto@bappenas.go.id 


\title{
Dampak Covid-19 terhadap Pergerakan Nilai Tukar Rupiah dan Indeks Harga Saham Gabungan (IHSG)
}

\author{
Haryanto
}

\section{Pendahuluan}

Penyebaran wabah COVID-19 yang begitu cepat di Indonesia telah memberikan pengaruh yang besar bagi ekonomi Indonesia. Lonjakan jumlah penderita dengan fatality rate yang tinggi dalam dua bulan terakhir, data akumulasi sejak 2 Maret-4 Mei 2020 sebanyak 11,192 kasus positif dan 8452 meninggal, sangat mengkhawatirkan dan menyebabkan kepanikan baik di kalangan pemerintah, masyarakat, maupun dunia usaha. Respon pemerintah dan masyarakat yang melakukan upaya pencegahan, seperti: penutupan sekolah, work from home khususnya pekerja sektor formal, penundaan dan pembatalan berbagai eventevent pemerintah dan swasta, penghentian beberapa moda transportasi umum, dan pemberlakuan PSBB di berbagai daerah, larangan mudik, membuat roda perputaran ekonomi melambat.

Tabel 1. Capital Outflows (Data per 13 April 2020)

\begin{tabular}{|c|c|c|c|c|}
\hline \multirow{2}{*}{$\begin{array}{c}\text { PIRANTI } \\
\text { (dalam triliun Rupiah) }\end{array}$} & \multicolumn{3}{|c|}{ Aliran Modal Asing 2020} & \multirow{2}{*}{$\begin{array}{l}\text { Aliran Modal } \\
\text { Asing } 2019\end{array}$} \\
\hline & 1-19 Jan & 20 Jan-13 Apr & year-to-date & \\
\hline $\mathrm{SBI}$ & $(2.30)$ & $(1.0)$ & (3.3) & 2.63 \\
\hline SBN* & 22.29 & $(165.8)$ & $(143.5)$ & 168.61 \\
\hline Obligasi Korporasi** & $(0.69)$ & 0.1 & $(0.6)$ & 3.01 \\
\hline Saham*** & 3.55 & $(15.4)$ & $(11.8)$ & 50.00 \\
\hline Total & 22.85 & $(182.1)$ & (159.3) & 224.24 \\
\hline \multicolumn{5}{|c|}{ * SBN (SPN+ON+SBSN); **Data diperoleh dari KSEI } \\
\hline
\end{tabular}

Sumber: bi.go.id

Kepanikan akibat Covid-19 juga melanda pasar keuangan Indonesia, dengan indikasi, bahwa selama periode penyebaran Corona Januari-13 April 2020 terjadi capital outflow yang jumlahnya mencapai Rp 159,3 triliun, sebagian besar merupakan surat berharga negara (SBN) Rp143,5 triliun (91\%), saham Rp11,8 triliun (7,4\%), SBI Rp3,3 triliun (2,1\%), dan obligasi korporasi Rpo,6 triliun (0,4\%) 3 ). Capital outflow dari investor asing selalu menimbulkan volatilitas yang tinggi baik pada pergerakan kurs Rp/US $\$$ maupun pergerakan indeks saham saat krisis.

Tercatat secara YTD, semenjak pandemi berlangsung 2 Maret hingga 16 April 2020, kurs rupiah terhadap US $\$$ terkoreksi (melemah) sebesar -12,4\% dan IHSG telah terkoreksi 28,44\%. Meskipun volatilitas tersebut masih tergolong lebih baik apabila dibandingkan dengan krisis finansial 2008, dimana saat itu, IHSG terkoreksi hingga 50\% dan Rupiah terdepresiasi sebesar 30,9\%; apabila wabah Covid 19 tidak diantisipasi secara dini, dapat mengakibatkan kepanikan secara luas dan berkepanjangan, dan timbul snowball effect, di

2) https://covid19.go.id/peta-sebaran, diakses Mei 2020

3) Bank Indonesia, Bersatu, Bertahan, Pulihkan Ekonomi: Koordinasi Kebijakan Nasional untuk Mitigasi Covid-19, Leadership Overview, 17 April 2020 
mana serbuan terhadap dollar AS makin lama makin besar, sehingga dampaknya bisa saja lebih buruk dari krisis keuangan tahun 2008.

Tidak hanya di Indonesia yang nilai tukar mata uangnya bergejolak, di negara lainpun, seperti: Colombia Peso turun 17,6\%, Rusia Ruble turun 18,5\%, Mexican Peso turun 25\%, Argentina Peso turun 9,4\%, Thai Baht turun 8,7\%, dan Canadian Dollar turun 7,5\%. Sebelum naiknya dolar karena dampak Covid-19, nilai tukar rupiah per dolar AS pada kisaran Rp.14.000/US\$ dan saat pandemi Covid-19, rupiah sempat terdepresiasi hingga Rp.16.600/ per US\$ nya. Kurs rupiah akan terus berada pada posisi rentan selama penyebaran wabah Covid-19, yang menyebabkan kepanikan di pasar global yang membuat dana asing kabur serta tekanan likuiditas dan desakan untuk mendapatkan dolar membuat dolar lebih unggul dari segalanya.

Fluktuasi rupiah, sebelum pandemi Covid-19 menurut sejumlah ekonom didorong sejumlah faktor baik eksternal dan internal. Pertama, ada kekhawatiran krisis keuangan yang terjadi di Argentina dan Turki menular ke negara berkembang yang mengalami defisit transaksi yang melebar, salah satunya Indonesia.

Kedua, sentimen kenaikan suku bunga acuan oleh bank sentral Amerika Serikat (Fed). Ketiga, risiko perang dagang antara Amerika Serikat dan China serta negara lainnya. Sedangkan faktor internal, Indonesia hadapi masalah defisit perdagangan dan defisit transaksi berjalan (CAD). Tercatat defisit transaksi berjalan sudah berjalan mencapai 3 persen dari Produk Domestik Bruto (PDB).

Pandemi Covid -19 tak sekadar mempengaruhi sisi kesehatan warga dunia. Wabah ini ikut menggerus perekonomian global dan merembet hingga ke Indonesia. Selain berimbas kepada nilai tukar, Covid-19 juga berdampak kepada penurunan Indeks Harga Saham Gabungan (IHSG) yang akhirnya terjun bebas. Semua berada di luar prediksi dan bukan hal yang mudah untuk dikendalikan. Sebelum konfirmasi COVID-19 pertama di Indonesia, IHSG berada pada level 6.244 (24 Jan) melemah ke 5.942 (20 Feb) dan terkoreksi lagi ke level 5.361 (2 Maret). Pada 12 Maret, saat WHO mengumumkan pandemi, IHSG jatuh 4,2 persen menjadi 4.937 ketika sesi Kamis dibuka, yang merupakan level yang tidak pernah terjadi selama hampir empat tahun terakhir. Pada 13 Maret, perdagangan saham dihentikan untuk pertama kalinya sejak 2008 karena pandemi Covid-19.

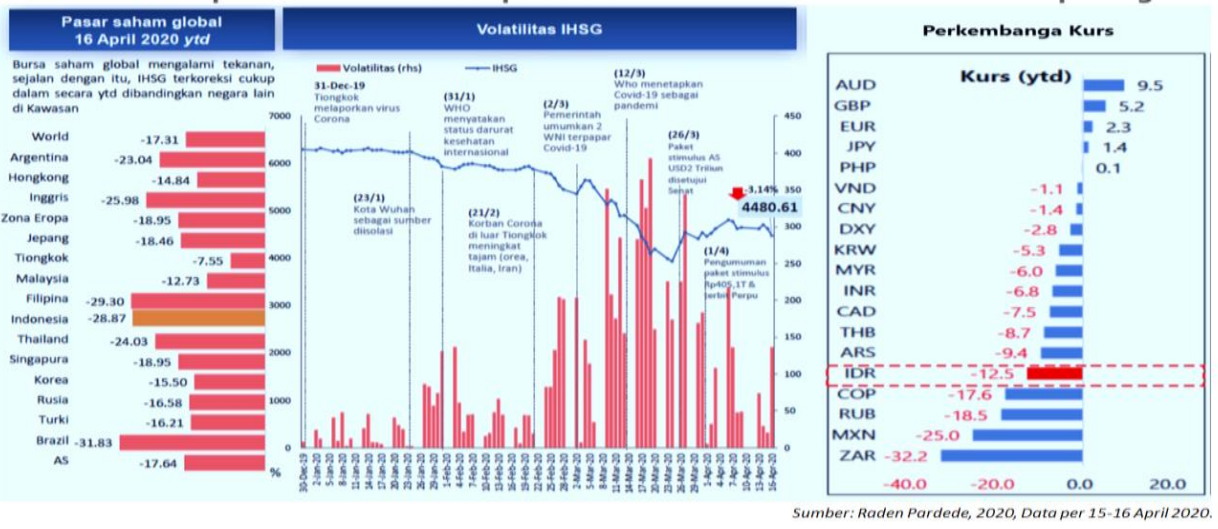

Gambar 1. Dampak Covid-19 terhadap Indeks Saham dan Nilai tukar di beberapa Negara

Sebagaimana terlihat dalam Gambar 1 di atas, per 16 April 2020, IHSG sempat terkorekasi sebesar 28,27\% sejak awal tahun 2020. Sementara itu, negara-negara lain juga 
mengalami hal yang sama, misalnya: PHISIX Philipina terkoreksi 29,3\%, SPI Singapore terkoreksi 18,95\%, SET Thailand 24,03\% dan LSE UK 25,98\%.

Nilai tukar rupiah masih berfluktuasi cenderung melemah, sementara pasar bursa pun meradang seiring laju Indeks Harga Saham Gabungan (IHSG) yang terkoreksi cukup dalam. Pertumbuhan ekonomi pun diperkirakan akan melambat drastis, terkikis oleh penjalaran dampak virus ke berbagai sektor di perekonomian. Untuk itu, cukup menarik untuk dilakukan analisis secara mendalam dampak pandemi Covid-19 terhadap pergerakan nilai tukar Rp/US\$ dan IHSG.

\subsection{Identifikasi Masalah}

Pandemi memang akan memperlambat roda perekonomian Indonesia, namun tanpa upaya sigap dari pemangku kebijakan untuk selamatkan nyawa penduduk Indonesia, maka optimisme perekonomian tidak akan pernah datang. Optimisme dan sentimen positif ekonomi baru akan terjadi jika pandemi COVID-19 dapat diatasi, setidaknya menunjukkan tanda-tanda terkendali dan akhirnya dapat diselesaikan. Masalahnya adalah sejauh mana pandemi Covid-19 ini akan berdampak terhadap perekonomian Indonesia yang dalam hal ini dalam ter-representasikan pada nilai tukar rupiah dan pergerakan IHSG? Kapan pandemi ini akan berakhir? Bagaimana antisipasi kebijakan dalam rangka mengurangi dampak Covid-19 terhadap fluktuasi nilai tukar dan IHSG? Ketiga permasalahan ini yang akan menjadi fokus dalam kajian.

\subsection{Tujuan}

Tujuan dari kajian ini adalah untuk :

a) Mengetahui sejauhmana dampak Covid-19 terhadap perubahan Nilai Tukar Rupiah/US\$

b) Mengetahui sejauhmana dampak Covid-19 terhadap perubahan IHSG

c) Mengetahui sejauhmana dampak Covid-19 dan perubahan IHSG terhadap perubahan Nilai Tukar Rupiah/US\$

d) Mengetahui sejauhmana dampak Covid-19 dan perubahan Nilai Tukar Rupiah/US\$ terhadap perubahan IHSG

e) Melakukan estimasi perkiraan outbreak dan berakhirnya penyebaran pandemi Covid-19 di Indonesia

f) Menyusun rekomendasi kebijakan dalam rangka stabilitas ekonomi (Kurs dan IHSG) melalui pengendalian penyebaran wabah Covid-19 dan peredaman kepanikan.

\subsection{Metodologi}

Metode yang digunakan dalam kajian ini adalah melalui desk study dan analisis kuantitatif model multiple linear regression, dengan beberapa simulasi model sbb:

$$
\begin{aligned}
& \text { KURS }=\beta 0+\beta 1 * \mathrm{C}-19+\mathrm{e} \\
& \mathrm{IHSG}=\beta 0+\beta 1 * \mathrm{C}-19+\mathrm{e} \\
& \mathrm{KURS}=\beta 0+\beta 1 * \mathrm{C}-19+\beta 2 * \text { IHSG }+\mathrm{e} \\
& \mathrm{IHSG}=\beta 0+\beta 1 * \mathrm{C}-19+\beta 2 * \text { KURS }+\mathrm{e}
\end{aligned}
$$

Data yang digunakan adalah data harian perkembangan kasus Covid-19, kurs tengah harian referensi Jisdor BI, dan data IHSG harian periode 2 Maret s/d 30 April 2020. Analisis data dengan melakukan transformasi ke bentuk logaritma. 


\subsection{Kerangka Pemikiran}

Saat nilai tukar bergerak sangat fluktuatif dapat disebabkan oleh berbagai faktor, diantaranya isu/sentimen pasar, biasanya nilai tukar suatu mata uang akan bergerak sangat cepat melampaui kondisi fundamentalnya. Biasanya hal ini berlangsung tidak terlalu lama bergantung kepada kondisi pasar valas domestik dan meredanya faktor spekulasi. Dengan berjalannya waktu, secara normal nilai tukar yang berfluktuasi melebihi kondisi fundamentalnya, akan kembali kepada kondisi keseimbangan fundamentalnya setelah mekanisme penyesuaian terjadi. Fluktuasi tajam nilai tukar dan gejolak harga Indeks saham tidak hanya semata-mata disebabkan oleh terjadinya krisis moneter saja, tetapi dapat disebabkan oleh berbagai musibah nasional yang datang secara bertubi-tubi di tengah kesulitan ekonomi, seperti pandemi Covid-19 yang melanda secara serempak di berbagai daerah bahkan berbagai negara sejak wabah Covid-19 mulai menjangkiti Wuhan yang diperkirakan semenjak pertengahan September 2019.

\section{Gambar 2: Kerangka Berfikir Kajian}

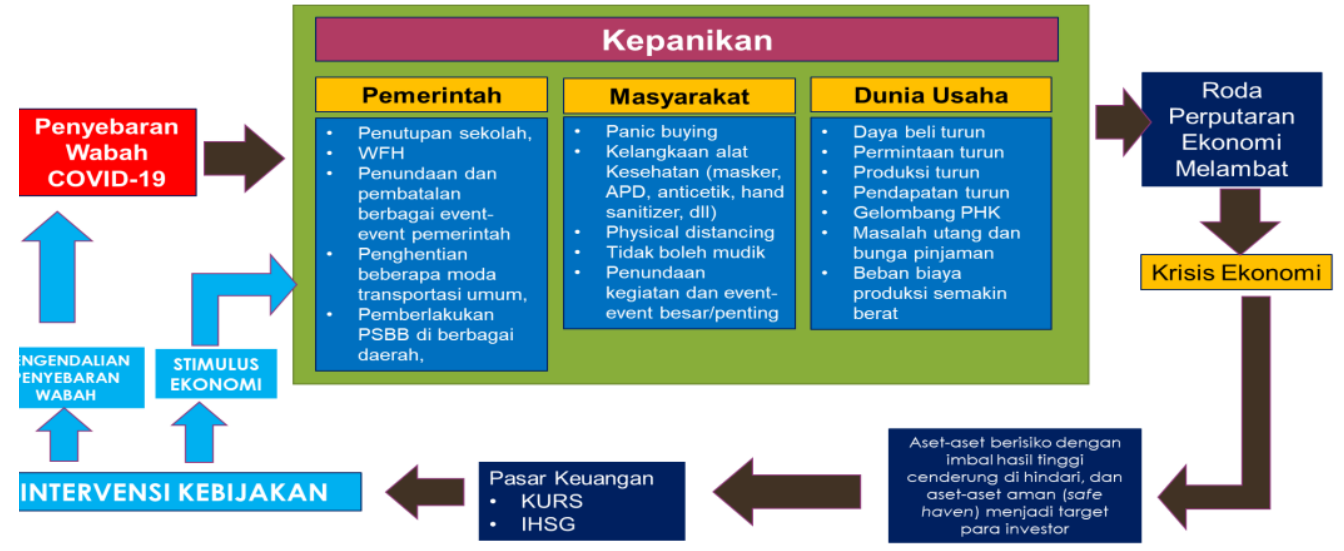

Gambar 2. Kerangka Berfikir Kajian

Sebagaimana ditunjukkan dalam Gambar 2, bahwa penyebaran wabah COVID-19 yang begitu cepat di Indonesia telah memberikan pengaruh yang besar bagi ekonomi nasional. Lonjakan jumlah penderita sangat cepat dalam waktu singkat menyebabkan kepanikan baik di kalangan pemerintah, masyarakat, maupun dunia usaha. Gejala kepanikan di sektor pemerintah ditunjukkan dengan respon seperti: penutupan sekolah, work from home khususnya pekerja sektor formal, penundaan dan pembatalan berbagai event-event pemerintah dan swasta, penghentian beberapa moda transportasi umum, dan pemberlakuan PSBB di berbagai daerah. Sementara, kepanikan di masyarakat terlihat dengan munculnya panic buying, kelangkaan alat kesehatan (masker, APD, antiseptic, hand sanitizer, dll), physical distancing, tidak boleh mudik, dan penundaan kegiatan dan event-event besar/penting, Di sektor dunia usaha, gejala kepanikan menyebabkan terjadinya penurunan daya beli, penurunan permintaan, penurunan produksi, pendapatan, dan beban biaya produksi yang semakin berat. Kepanikan tersebut berdampak pada melambatnya roda perputaran ekonomi yang akan memicu timbulnya krisis ekonomi. Sudah menjadi gejala alami bahwa dalam 
kondisi krisis, para investor global akan lebih tertarik untuk menyimpan kekayaannya dalam bentuk aset yang aman dan menghindari aset beresiko, seperti memegang mata uang yang rentan terhadap fluktuasi yang salah satunya mata uang Rupiah, dan aset-aset seperti saham. Kondisi ini tentunya akan mendorong mata uang negara-negara sedang berkembang menjadi terdepresiasi terhadap mata uang kuat dari negara maju seperti US $\$$, dan juga berdampak kepada turunnya harga-harga saham negara berkembang termasuk Indonesia. Dalam hal ini, maka penting bagi pemerintah untuk mengambil langkah-langkah strategis dalam stabilisasi ekonomi dalam meredam kepanikan dan mengendalikan kepada penyebab kepanikan di masyarakat.

\section{Analisis dan Pembahasan}

Analisis dalam kajian akan berfokus pada lima hal, yaitu: dampak Covid-19 terhadap perubahan Nilai Tukar Rupiah/US\$, dampak Covid-19 terhadap perubahan IHSG, dampak Covid-19 dan perubahan IHSG terhadap perubahan Nilai Tukar Rupiah/US $\$$, dampak Covid-19 dan perubahan Nilai Tukar Rupiah/US\$ terhadap perubahan IHSG, dan estimasi perkiraan outbreak dan berakhirnya penyebaran pandemi Covid-19 di Indonesia. Metode analisis dengan menggunakan model multiple linear regression. Data meliputi, data harian perkembangan C-19, kurs tengah harian referensi Jisdor BI, dan data IHSG harian periode 2 Maret sd 30 April 2020, dengan melakukan transformasi dalam bentuk logaritma.

\section{a. Dampak Covid-19 terhadap perubahan Nilai Tukar Rupiah/US\$}

Hasil analisis regresi dampak Covid-19 terhadap perubahan Nilai Tukar Rupiah/US\$ terlihat dalam Tabel 2 berikut:

Tabel 2. Summary Output Covid-19 to Kurs

\begin{tabular}{|c|c|c|c|c|c|c|c|c|}
\hline TABEL 2: SUMMAR & OUTPUT COVII & D-19 TO KURS & & & & & & \\
\hline \multicolumn{9}{|c|}{ Regression Statistics } \\
\hline Multiple R & 0.748807803 & & & & & & & \\
\hline R Square & 0.560713126 & & & & & & & \\
\hline Adjusted R Square & 0.553139214 & & & & & & & \\
\hline Standard Error & 0.014786699 & & & & & & & \\
\hline Observations & 60 & & & & & & & \\
\hline \multirow{2}{*}{\multicolumn{9}{|c|}{ ANOVA }} \\
\hline & & & & & & & & \\
\hline & $d f$ & SS & MS & $F$ & Significance $F$ & & & \\
\hline Regression & 1 & 0.016186873 & 0.016186873 & 74.03217169 & $6.00039 \mathrm{E}-12$ & & & \\
\hline Residual & 58 & 0.012681496 & 0.000218646 & & & & & \\
\hline \multirow[t]{2}{*}{ Total } & 59 & 0.028868369 & & & & & & \\
\hline & Coefficients & Standard Error & $t$ Stat & P-value & Lower 95\% & Upper $95 \%$ & Lower $95.0 \%$ & Upper $95.0 \%$ \\
\hline Intercept & 4.154740908 & 0.004785493 & 868.1949932 & $5.2121 \mathrm{E}-121$ & 4.145161703 & 4.164320112 & 4.145161703 & 4.164320112 \\
\hline Log COVID-19 & 0.020350945 & 0.002365235 & 8.604195005 & $6.00039 \mathrm{E}-12$ & 0.015616412 & 0.025085478 & 0.015616412 & 0.025085478 \\
\hline
\end{tabular}

Sebagaimana terlihat dalam Tabel 2, model persamaan yang dibangun cukup baik, hal ini terlihat dari uji $\mathrm{F}$, dengan tingkat keyakinan $95 \%$ nilai $\mathrm{F}<0,05$ mengandung makna bahwa variabel Covid-19 berpengaruh terhadap pergerakan nilai tukar rupiah terhadap US $\$$. Meskipun nilai $\mathrm{R}$ tidak terlalu tinggi $(0,55)$, namun dapat dimaknai bahwa dampak C-19 terhadap fluktuasi Kurs cukup signifikan sebagaimana tersirat dalam koefisien variabel C19. Dari hasil analisis dapat dijelaskan bahwa semakin tinggi kasus C-19 berdampak kepada semakin tingginya rupiah yang diperlukan untuk membeli satu US $\$$. Hal ini berarti, semakin tinggi kasus C-19, maka nilai Rupiah semakin terdepresiasi terhadap US\$. Besarnya koefisien variabel C-19 sebesar 0,02 berarti bahwa setiap ada kenaikan 1\% kasus C-19, akan 
menyebabkan depresiasi nilai mata uang Rupiah terhadap US\$ sebesar 0,02\%. Dengan temuan ini, maka mendorong keyakinan bahwa upaya-upaya memitigasi penyebaran Kasus Covid-19 menjadi sangat penting agar dampaknya kepada ekonomi tidak semakin memburuk.

\section{b. Dampak Covid-19 terhadap perubahan IHSG.}

Hasil analisis regresi dampak Covid-19 terhadap pergerakan Indeks Harga Saham Gabungan terlihat dalam Tabel 3 berikut:

Tabel 3. Summary Output Covid-19 to IHSG

\begin{tabular}{|c|c|c|c|c|c|c|c|c|}
\hline \multicolumn{9}{|c|}{ TABEL 3: SUMMARY OUTPUT COVID-19 TO IHSG } \\
\hline \multicolumn{9}{|c|}{ Regression Statistics } \\
\hline Multiple R & 0.701783798 & & & & & & & \\
\hline R Square & 0.492500499 & & & & & & & \\
\hline Adjusted R Square & 0.483750508 & & & & & & & \\
\hline Standard Error & 0.026017331 & & & & & & & \\
\hline Observations & 60 & & & & & & & \\
\hline \multicolumn{9}{|l|}{ ANOVA } \\
\hline & $d f$ & SS & MS & $F$ & Significance $F$ & & & \\
\hline Regression & 1 & 0.03809996 & 0.03809996 & 56.28582669 & 4.19383E-10 & & & \\
\hline Residual & 58 & 0.039260286 & 0.000676901 & & & & & \\
\hline \multirow[t]{2}{*}{ Total } & 59 & 0.077360246 & & & & & & \\
\hline & Coefficients & Standard Error & t Stat & P-value & Lower 95\% & Upper 95\% & Lower $95.0 \%$ & Upper $95.0 \%$ \\
\hline Intercept & 3.726674797 & 0.008420118 & 442.5917701 & $4.8518 \mathrm{E}-104$ & 3.7098201 & 3.743529493 & 3.7098201 & 3.743529493 \\
\hline Log COVID-19 & -0.031222333 & 0.004161653 & -7.502388066 & 4.19383E-10 & -0.039552786 & -0.02289188 & -0.039552786 & -0.02289188 \\
\hline
\end{tabular}

Tabel 3 merupakan hasil model persamaan yang dibangun untuk melihat pengaruh Covid-19 terhadap pergerakan IHSG. Uji F dengan tingkat keyakinan 95\% nilai $\mathrm{F}<0,05$ menunjukkan bahwa model cukup baik dalam menjelaskan dampak C-19 terhadap pergerakan IHSG. Meskipun nilai R tidak terlalu tinggi $(0,48)$, namun dapat dimaknai pula bahwa dampak C-19 terhadap fluktuasi IHSG cukup signifikan sebagaimana tersirat dalam koefisien variabel C-19. Tanda minus pada koefisien C-19 berimplikasi bahwa semakin tinggi kasus C-19 berdampak kepada penurunan IHSG. Hal ini berarti, semakin tinggi kasus C-19, maka Indeks Harga Saham Gabungan akan semakin terkoreksi. Besarnya koefisien variabel C-19 sebesar -0,03 berarti bahwa setiap ada kenaikan 1\% kasus C-19, akan menyebabkan koreksi terhadap Indeks Harga Saham Gabungan sebesar 0,03\%. Temuan ini mendorong keyakinan bahwa upaya-upaya memitigasi penyebaran Kasus Covid-19 menjadi sangat penting agar pasar saham di Indonesia tidak semakin memburuk. Memburuknya kondisi pasar saham ini tentu saja akan berdampak kepada sektor riil.

Peran bursa saham sebagai salah satu instrumen pertumbuhan ekonomi dan percepatan pembangunan terjadi melalui transmisi pada sektor-sektor riil. Pasar modal sangat penting untuk memenuhi kebutuhan investasi pembangunan ekonomi yang sedang berjalan. Di banyak negara maju, instrumen pasar modal merupakan salah satu sumber pembiayaan pembangunan di berbagai sektor. Penggunaan pasar modal sebagai media intermediasi bagi pendanaan investasi dapat membuat struktur pendanaan perusahaan menjadi lebih terdiversifikasi dan lebih efisien dalam hal biaya. 


\section{c. Dampak Covid-19 dan IHSG terhadap pergerakan nilai tukar Rupiah/US\$}

Analisis multiple regression dilakukan untuk mengetahui konsistensi dampak Covid-19 terhadap nilai tukar. Model yang dibangun adalah simulasi secara bersama-sama dampak variabel Covid-19 dan IHSG terhadap nilai tukar rupiah. Hasil analisis terlihat dalam Tabel 4 berikut:

Tabel 4. Summary Output Covid-19 IHSG to Kurs

\begin{tabular}{|c|c|c|c|c|c|c|c|c|}
\hline \multicolumn{9}{|c|}{ TABEL 4: SUMMARY OUTPUT COVID-19, IHSG TO KURS } \\
\hline \multicolumn{9}{|c|}{ Regression Statistics } \\
\hline Multiple R & 0.831939176 & & & & & & & \\
\hline R Square & 0.692122793 & & & & & & & \\
\hline Adjusted R Square & 0.681320084 & & & & & & & \\
\hline Standard Error & 0.012487125 & & & & & & & \\
\hline Observations & 60 & & & & & & & \\
\hline \multicolumn{9}{|l|}{ ANOVA } \\
\hline & $d f$ & SS & MS & $F$ & Significance $F$ & & & \\
\hline Regression & 2 & 0.019980456 & 0.00999 & 64.06937306 & $2.62277 \mathrm{E}-15$ & & & \\
\hline Residual & 57 & 0.008887913 & 0.000156 & & & & & \\
\hline \multirow[t]{2}{*}{ Total } & 59 & 0.028868369 & & & & & & \\
\hline & Coefficients & Standard Error & tStat & $P$-value & Lower 95\% & Upper 95\% & Lower $95.0 \%$ & Upper $95.0 \%$ \\
\hline Intercept & 5.313170246 & 0.23489378 & 22.61946 & $3.74789 \mathrm{E}-30$ & 4.842803566 & 5.783536927 & 4.842803566 & 5.783536927 \\
\hline Log IHSG & -0.310847982 & 0.063021064 & -4.93245 & 7.39183E-06 & -0.437045486 & -0.184650477 & -0.437045486 & -0.184650477 \\
\hline Log COVID-19 & 0.010645546 & 0.002803805 & 3.796822 & 0.000357613 & 0.005031024 & 0.016260068 & 0.005031024 & 0.016260068 \\
\hline
\end{tabular}

Model persamaan multiple regression sebagaimana yang dibangun pada Tabel 4 di atas memperlihatkan hasil analisis yang cukup baik. Hal ini terlihat dari uji F, dengan tingkat keyakinan 95\% nilai $\mathrm{F}<0$,05 mengandung makna bahwa variabel pandemi C-19 dan IHSG secara bersama-sama berpengaruh terhadap pergerakan nilai tukar rupiah terhadap US $\$$. Nilai R semakin meningkat dibandingkan dengan uji parsial $(0,68)$, dapat dimaknai bahwa variabel C-19 dan IHSG secara bersama-sama dapat menjelaskan sebesar $68 \%$ pergerakan fluktuasi Kurs pada saat periode pengamatan. Besarnya dampak masing-masing variabel terlihat pada besaran koefisien masing-masing variabel C-19 dan IHSG.

Hasil analisis konsisten dengan temuan sebelumnya bahwa semakin tinggi kasus C19 akan berdampak pada semakin terdepresiasinya nila tukar rupiah terhadap US $\$$, yang berarti semakin tinggi rupiah yang diperlukan untuk mendapatkan satu US\$. Koefisien Covid-19 sebesar 0,011 berarti setiap ada penambahan kasus Covid-19 sebesar 1\% akan berdampak kepada depresiasi nilai tukar rupiah terhadap US\$ sebesar 0,11\%.

Sementara itu, koefisien IHSG sebesar -0,311 mengandung makna bahwa IHSG dan nilai tukar berhubungan secara negatif, dimana setiap terjadi peningkatan $1 \%$ IHSG akan mengakibatkan penurunan kebutuhan Rupiah yang diperlukan untuk mendapatkan 1US\$, yang berarti rupiah akan menguat (terapresiasi) sebesar 0,311\%. Secara logis, temuan ini menjelaskan bahwa terdepresiasinya rupiah dapat meningkatkan pendapatan perusahaan yang berorientasi ekspor sehingga nilai IHSG di BEI akan semakin meningkat. 


\section{d. Dampak Covid-19 dan nilai tukar Rupiah/US\$ terhadap pergerakan IHSG}

Model persamaan ini dikembangkan untuk menjelaskan sejauhmana variabel nilai tukar dan Covid-19 menjelaskan pergerakan IHSG. Hasil analisis terlihat dalam Tabel 5 berikut:

Tabel 5. Summary Output Covid-19 Kurs to IHSG

\begin{tabular}{|c|c|c|c|c|c|c|c|c|}
\hline \multicolumn{9}{|c|}{ TABEL 5: SUMMARY OUTPUT COVID-19, KURS TO IHSG } \\
\hline \multicolumn{9}{|c|}{ Regression Statistics } \\
\hline Multiple R & 0.802692661 & & & & & & & \\
\hline R Square & 0.644315508 & & & & & & & \\
\hline Adjusted R Square & 0.63183535 & & & & & & & \\
\hline Standard Error & 0.021971209 & & & & & & & \\
\hline Observations & 60 & & & & & & & \\
\hline \multirow{2}{*}{\multicolumn{9}{|c|}{ ANOVA }} \\
\hline & & & & & & & & \\
\hline & $d f$ & SS & MS & $F$ & Significance $F$ & & & \\
\hline Regression & 2 & 0.049844406 & 0.024922 & 51.62719317 & $1.60454 \mathrm{E}-13$ & & & \\
\hline Residual & 57 & 0.02751584 & 0.000483 & & & & & \\
\hline \multirow[t]{2}{*}{ Total } & 59 & 0.077360246 & & & & & & \\
\hline & Coefficients & Standard Error & t Stat & P-value & Lower 95\% & Upper 95\% & Lower $95.0 \%$ & Upper 95.1 \\
\hline Intercept & 7.724971179 & 0.810642511 & 9.529442 & $2.13416 \mathrm{E}-13$ & 6.101687551 & 9.348254808 & 6.101687551 & 9.348254 \\
\hline Log KURS & -0.96234554 & 0.195105144 & -4.93245 & 7.39183E-06 & -1.353036853 & -0.571654228 & -1.353036853 & -0.571654 \\
\hline Log COVID-19 & -0.011637692 & 0.005302528 & -2.19474 & 0.032270899 & -0.022255821 & -0.001019564 & -0.022255821 & -0.001019 \\
\hline
\end{tabular}

Dari Tabel 5 di atas dapat dijelaskan bahwa hasil analisis model persamaan yang dikembangkan menunjukkan hasil yang cukup baik. Hal ini terlihat dari uji $\mathrm{F}$, dengan tingkat keyakinan 95\%, dimana nilai $\mathrm{F}<0,05$ yang berarti bahwa variabel pandemi C-19 dan Nilai Tukar secara bersama-sama mempunyai pengaruh yang cukup baik terhadap pergerakan IHSG. Nilai adjusted $R$ square yang semakin meningkat dibandingkan dengan uji parsial $(0,63)$, dapat dimaknai bahwa variabel $\mathrm{C}-19$ dan nilai tukar secara bersama-sama mampu menjelaskan sebesar $63 \%$ pergerakan fluktuasi IHSG pada saat periode pengamatan. Besarnya dampak masing-masing variabel terlihat pada besaran koefisien masing-masing variable C-19 dan nilai tukar.

Hasil analisis melalui persamaan berganda tetap konsisten dengan hasil sebelumnya bahwa semakin tinggi kasus C-19 akan berdampak pada semakin melemahnya IHSG. Koefisien Covid-19 sebesar -0,012 berarti setiap ada penambahan kasus Covid-19 sebesar 1\% akan berdampak kepada penurunan IHSG sebesar $0,12 \%$.

Sementara itu, koefisien nilai tukar sebesar --0,962 mengandung makna bahwa setiap nilai tukar terdepresiasi sebesar 1\% maka IHSG akan mengalami peningkatan sebesar $0,962 \%$ (ceteris paribus). Secara logis, temuan ini masih tetap konsisten dengan hasil analisis sebelumnya bahwa peningkatan IHSG akan mendorong orang untuk menjual asetnya dalam bentuk US $\$$ dan beralih untuk investasi di pasar saham domestik karena prospek imbal balik yang lebih besar dari kenaikan harga saham.

\section{Pembahasan}

Perilaku yang terjadi hubungan antara Covid-19, nilai tukar dan IHSG selama pandemi C-19 sebagaimana yang dijelaskan di atas adalah kondisi dimana pemerintah (BI, OJK, dan Kemkeu, BEI) telah melakukan berbagai bauran kebijakan fiskal dan moneter 
dalam rangka memitigasi dampak yang berkepanjangan dari wabah C-19. Tanpa intervensi kebijakan maka dampak C-19 terhadap nilai tukar dan IHSG akan lebih dalam.

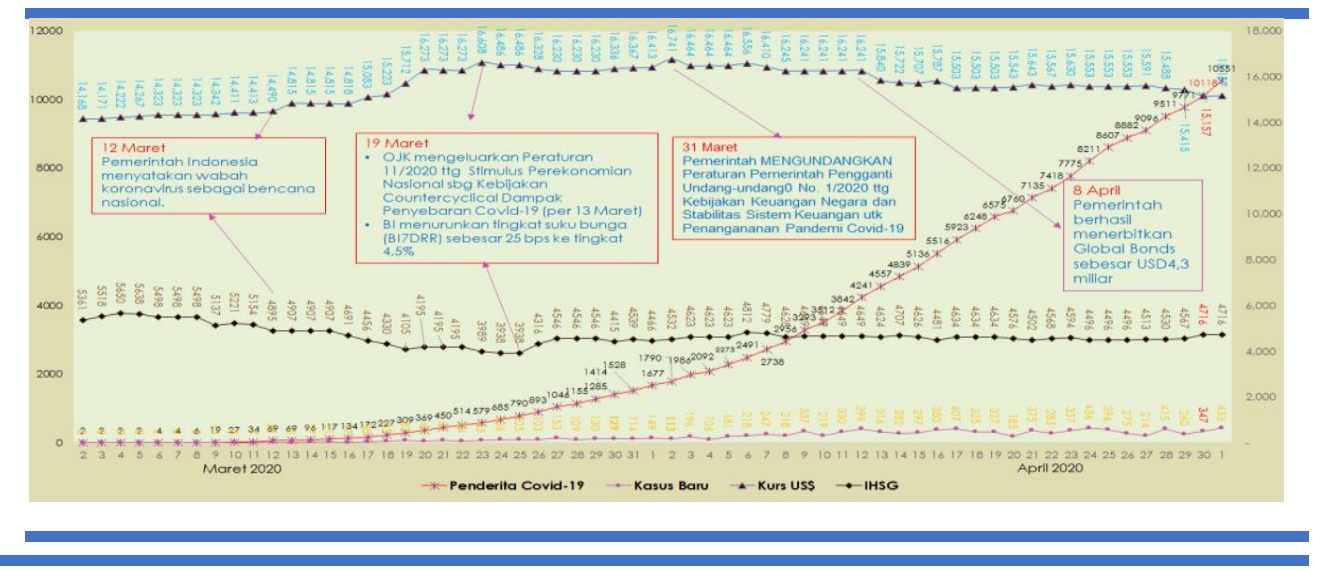

Gambar 3. Perkembangan Kasus C-19, Nilai Tukar dan IHSG Harian 2 Maret sd 1 Mei 2020

Upaya memitigasi pelemahan nilai tukar rupiah terhadap US $\$$, sudah dilakukan beberapa kali oleh BI dengan meracik bauran kebijakan agar rupiah tetap terjaga, di antaranya adalah dengan:

a. Intervensi Cadangan Devisa sebesar US\$7 miliar untuk stabilkan mata uang Rupiah. Sementara itu, USD2,4 miliar dikeluarkan untuk membayar utang pemerintah yang jatuh tempo.

b. Menurunkan suku bunga kebijakan BI7DDR pada Februari dan Maret, masingmasing sebesar $25 \mathrm{bps}$,

c. Meningkatkan intensitas triple intervention di pasar spot, DNDF, dan pembelian SBN di pasar sekunder,

d. Menurunkan Giro Wajib Minimum (GWM) Valas bank umum konvensional dari semula $8 \%$ menjadi $4 \%$,

e. Memperpanjang tenor repo SBN dan lelang tiap hari untuk memperkuat pelonggaran likuiditas rupiah dan menambah frekuensi lelang FX Swap menjadi setiap hari untuk memastikan kecukupan likuiditas,

f. Memperluas jenis underlying transaksi DNDF sehingga dapat mendorong lindung nilai atas kepemilikan Rupiah di Indonesia

g. Menurunkan GWM Rupiah sebesar 5obps untuk bank yang melakukan kegiatan ekspor-impor, pembiayaan kepada UMKM dan/atau sektor prioritas lain,

h. Melonggarkan ketentuan Rasio Intermediasi Makroprudensial (RIM),

i. Menyediakan uang higienis, menurunkan biaya SKNBI, penetapan MDR QRIS O\% untuk merchant usaha mikro, dan mendukung penyaluran dana non-tunai programprogram pemerintah seperti Program Bantuan Sosial PKH dan BNPT, Program Kartu Prakerja, dan Kartu Indonesia Pintar.

j. Melakukan intervensi pasar dengan surat utang berdenominasi dolar Amerika Serikat (AS) sebesar USD4,3 miliar. Penerbitan surat berharga global ini dilakukan dalam tiga bentuk yaitu Surat Berharga Negara (SBN) seri RI1030, RI 1050, dan RI 0470 . 
Sementara itu, dalam menghadapi gejolak pasar saham sebagai imbas mewabahnya virus corona BEI telah menerapkan kebijakan auto rejection asimetris dan trading halt selama 30 menit. Kebijakan tersebut dapat memberikan waktu bagi investor untuk lebih rasional dalam menghadapi fluktuasi pasar. Sehingga, investor tidak terbawa arus dalam mencermati perkembangan pasar. Salah satu bukti keberhasilan kebijakan itu dalam menahan penurunan IHSG, terutama oleh kebijakan trading halt, IHSG ditutup tidak turun lebih dari $5 \%$ bahkan di zona hijau. Sejak diterapkan hingga kini, tercatat sudah 6 kali Bursa menghentikan perdagangan di pasar saham selama 30 menit karena IHSG turun 5\%.

\section{e. Estimasi Penyebaran Covid-19}

Berbagai perhitungan dilakukan oleh para peneliti untuk memprediksi kapan pandemi Covid-19 di Indonesia akan berakhir. Berbagai metode dan asumsi dibangun untuk melakukan analisis penyebaran virus corona. Kesimpulan yang dapat ditarik dari prediksi para peneliti tersebut adalah sebagai berikut:

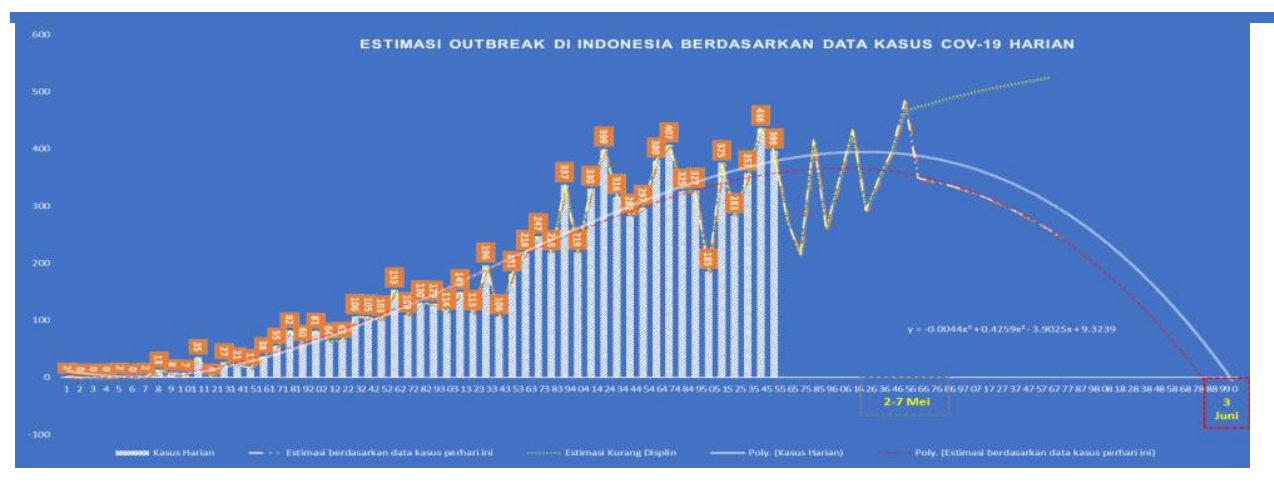

Gambar 4. Estimasi Penyebaran Covid-19

i. $\quad$ Periode titik puncak mayoritas penelitian memprediksi terjadi sekitar bulan Mei 2020, bila diberlakukan kebijakan yang tegas dan strategis dalam mengurangi interaksi antar manusia (masyarakat disiplin mengimplementasikan physical distancing/ PSBB)

ii. Pada periode ini, diprediksi pertambahan jumlah kasus harian sudah mulai melambat.

iii. Periode kritis diprediksi terjadi pada minggu kedua bulan April hingga awal Mei 2020 di mana tingkat pertambahan harian akan meningkat cukup tajam

iv. Periode pemulihan diprediksi paling cepat pada 110 hari hingga 150 hari

Penulis juga mencoba melakukan estimasi berdasarkan data harian yang dirilis oleh Gugus Tugas Pengendalian C-19, dengan model sederhana extrapolasi polynomial order tiga, menghasilkan estimasi (sebagaimana Gambar 4), dengan penjelasan sebagai berikut:

i. Basis data adalah kasus harian mulai 2 Maret s/d 25 April 2020 (grafik poly -kasus harian)

ii. Outbreak (puncak) kasus harian C-19, berdasarkan model tersebut, diperkirakan akan terjadi pada minggu pertama bulan Mei, atau hari ke $62 \mathrm{~s} / \mathrm{d}$ hari ke 67, sejak kasus pertama diumumkan yaitu 2 Maret 2020 
iii. Perkiraan kasus C-19 akan berakhir sekitar hari ke 96, atau minggu pertama bulan Juni 2020

iv. Hingga minggu pertama bulan Juni tersebut, total kasus diperkirakan sebanyak $20.000 \mathrm{~s} / \mathrm{d} 22.000$ kasus.

v. Estimasi ini didasarkan perilaku perkembangan data harian hingga 25 April 2020

vi. Apabila terjadi perubahan kasus harian yang cukup signifikan, misalnya tiba-tiba dilakukan tes PCR secara massal (misalnya rasio tes adalah $>3$ orang per 1000 penduduk, perlu diketahui sumber dari ourworldindata.org, menyebutkan bahwa saat ini rasio jumlah yang dites dengan PCR di Indonesia adalah 0,19 per 1000 penduduk), atau masyarakat tidak disiplin, tidak mengikuti peraturan pemerintah, dan ditemukan jumlah angka secara extraordinary, maka dapat terjadi pergeseran kurva dan estimasi yang cukup signifikan pula.

vii. Asumsinya adalah pelaksanaan PSBB diikuti dengan penegakan disiplin, tidak ada mudik, psysical distancing diterapkan secara ketat.

\section{Kesimpulan Dan Rekomendasi Kebijakan}

\subsection{Kesimpulan}

Berdasarkan hasil simulasi melalui model kuantitatif multiple linear regression pada kajian ini, secara umum dapat disimpulkan bahwa pandemi covid-19 berdampak secara nyata terhadap fluktuasi nilai tukar Rp/US\$ dan fluktuasi IHSG. Adapun temuan secara rinci dapat dijelaskan sebagai berikut:

a. Uji secara parsial menjelaskan bahwa kenaikan 1\% kasus C-19, akan menyebabkan depresiasi nilai mata uang Rupiah terhadap US\$ sebesar 0,02\%.

b. Uji secara parsial juga menjelaskan bahwa setiap ada kenaikan $1 \%$ kasus C-19, akan menyebabkan koreksi terhadap Indeks Harga Saham Gabungan sebesar 0,03\%.

c. Uji persamaan melalui model persamaan berganda menjelaskan bahwa hasil analisis konsisten dengan temuan uji secara parsial dimana semakin tinggi kasus C-19 akan berdampak pada semakin terdepresiasinya nila tukar rupiah terhadap US\$, yang berarti semakin tinggi rupiah yang diperlukan untuk mendapatkan satu US\$.

d. Hasil analisis melalui persamaan berganda dengan IHSG sebagai variabel dependen tetap konsisten dengan hasil uji parsial bahwa semakin tinggi kasus C-19 akan berdampak pada semakin melemahnya IHSG.

e. Berdasarkan data riel kasus harian Covid-19 yang dirilis oleh Gugus Percepatan Penanganan Wabah C-19 per 2 Maret sd 25 April 2020, maka diperkirakan hal-hal sebagai berikut:

$\checkmark$ Outbreak (puncak) kasus harian C-19, berdasarkan, diperkirakan akan terjadi pada minggu pertama bulan Mei, atau hari ke $62 \mathrm{~s} / \mathrm{d}$ hari ke 67 , sejak kasus pertama diumumkan pada 2 Maret 2020

$\checkmark$ Perkiraan kasus C-19 akan berakhir sekitar hari ke 96, atau minggu pertama bulan Juni 2020

$\checkmark$ Hingga minggu pertama bulan Juni tersebut, total kasus diperkirakan sebanyak $20.000 \mathrm{~s} / \mathrm{d} 22.000$ kasus.

$\checkmark$ Asumsi permodelan didasarkan kepada pelaksanaan PSBB diikuti dengan penegakan disiplin, tidak ada mudik, psysical distancing diterapkan secara ketat dan tidak ada kasus harian yang bersifat extraordinary. 


\subsection{Rekomendasi Kebijakan}

Berdasarkan kesimpulan di atas, maka terdapat tiga rekomendasi utama, yaitu perlunya kebijakan pengendalian secara cepat penyebaran pandemi Covid-19, perlunya kebijakan untuk meredam kepanikan yang terjadi di masyarakat, dan perlunya kebijakan untuk meredam kepanikan yang terjadi di dunia usaha.

\subsubsection{Saran Kebijakan Pengendalian Penyebaran Pandemi Covid-19, di antaranya:}

a. Mengembangkan konsep Rencana Kerja Pemerintah yang Adaptif

b. Menegakkan disiplin (bila perlu mendenda pelanggar) dalam penerapan PSBB

c. Mengembangkan dan menyempurnakan Big Data yang menggambarkan peta kesehatan masyarakat dan mobilitasnya sehingga mempermudah tracing masyarakat yang ODP, PDP, dan positif

d. Kolaborasi Pemerintah, BUMN/BUMD, swasta untuk penyediaan secara cepat dan masif alat pelindung diri (APD) dan Alkes lainnya di RS-RS rujukan dan nonrujukan.

e. Bappenas bersama Kemenkeu, dan (Kemenkes) segera melakukan refocusing dan evaluasi Program/Kegiatan K/L/Pemda pada APBN 2020 untuk penyiapan penanggulangan wabah Covid-19

f. Terus mengoptimalkan peran Gugus Tugas Bappenas, khususnya terkait penelaahan dampak, rencana operasional, kontinjensi \& pemulihan ekonomi-sosial, dan bagaimana dampak Covid-19 ini akan diskenario-kan dalam dokumen perencanaan yang lebih adaptif (RKP 2020?, RKP 2021, dan RPJMN 2020-2024).

g. Penyiapan financing source (scenario) untuk mengantisipasi bilamana revenue negara jatuh melampaui 10\%, dengan melakukan pembicaraan secara bilateral ataupun multilateral dengan negara/lembaga lain.

h. Secara terus menerus memperbaiki kualitas dan kuantitas medis (tenaga, fasilitas, obat, alat-alat medis, dll) dan perkuat lembaga-lembaga riset bidang kesehatan

\subsubsection{Saran Kebijakan untuk Meredam Kepanikan Masyarakat, di antaranya dengan melakukan:}

a. Antisipasi tren restriksi pangan global dengan segera melakukan evaluasi neraca pangan nasional antar kementerian dan lembaga terkait. Jika memang perlu dilakukan impor, segerakan impor saat ini dengan pemberian fasilitas impor dari Kemendag

b. Penyemprotan desinfektan (fasum, fasus) secara masif seminggu 2 kali

c. Bantuan yang bersifat langsung kepada masyarakat marginal harus segera didisburse untuk mengantisipasi dampak ekonomi nasional, dan memastikan anggaran untuk jaring pengaman sosial yaitu bantuan bagi masyarakat diterima oleh mereka yang rentan akibat wabah ini.

d. Perluas cakupan pemeriksaan spesimen dengan pengujian PCR dan pembatasan gerak warga yang wilayahnya sudah jadi pusat penyebaran Covid-19.

e. Penguatan social engineering melalui model jaringan pentahellix (Pemerintah, Pasar Jaya, Telkom, Gojek, masyarakat)

f. Menjaga ketersediaan kebutuhan pokok, dan menyiapkan cara-cara mendistribusikan bahan kebutuhan pokok. 


\subsubsection{Saran Kebijakan untuk Meredam Kepanikan Dunia Usaha, di antarnya:}

a. Relaksasi PPh21, PPh22, PPh25 dan pembebasan PPN (dalam kurun 6 bulan). Instrumen diberikan terbatas, bergantung pada sektor yang paling terdampak dan sasaran pada sektor padat karya khususnya UMKM manufaktur dan UMKM pariwisata.

b. Pembebasan iuran BPJS Kesehatan dan Ketenagakerjaan (dalam kurun 6 bulan)

c. Insentif bagi industri yang mengubah lini produksinya menjadi pemenuhan kebutuhan medis, dengan sasaran: perusahaan farmasi, elektronik dan tekstil

d. Kelonggaran utang dan bunga kredit.

\section{Daftar Pustaka}

Arman, Helmi, Indonesia Macro Prospects 2020: Reforms overshadowed by nearterm growth headwinds. Citi Research, Jakarta: 23 Maret 2020

BI, Bersatu, Bertahan, Pulihkan Ekonomi: Koordinasi Kebijakan Nasional untuk Mitigasi Covid-19, Leadership Overview, Jakarta: 17 April 2020

BI, Konsep, Dinamika dan Respon Kebijakan nilai Tukar di Indonesia. Seri Kebanksentralan No. 24, Jakarta: 2015.

Cochrane, Steve, dkk. A Global Recession A Briefing Exclusively for Indonesia. Moody's Analitics, April 2020.

Lilik Salamah, Lingkaran Krisis Ekonomi Indonesia, Jurnal: Masyarakat, Kebudayaan dan Politik, Th XIV, No 2, April 2001, 65-76.

McKinsey \& Company. Covid-19: Briefing Material, Global Health and Crisis Response, 25 Maret 2020.

Miranda S. Goeltom dan Doddy Zulverdi, Manajemen Nilai Tukar di Indonesia dan Permasalahannya. Buletin Ekonomi Moneter dan Perbankan, September 1998

Nugroho, A. Satyrio. Solusi dan Mitigasi Sektor Ekonomi Terdampak Pandemi covid-19. INDEF, Jakarta: April 2020

Pardede, R. Perkembangan Ekonomi Dunia dan Indonesia serta respon kebijakan terhadap krisis COVID-19. Materi Seminar.

https://experience.arcgis.com/experience/bf4eb5d76e98423c865678e32c8937d4

https://id.wikipedia.org/wiki/Pandemi_koronavirus_di_Indonesia\#6_Maret

https://covid 19.kemkes.go.id/situasi-infeksi-emerging/info-corona-virus/situasi-terkiniperkembangan-covid-19-17-maret-2020/\#.XnNpWagzZPY

https://www.thejakartapost.com/news/2020/03/10/indonesia-confirms-first-possiblecovid-19-community-transmission-as-cases-rise-to-27.html

https://kaltim.tribunnews.com/2020/03/20/kabar-baik-jokowi-akan-bagikan-dua-jenisobat-virus-corona-sudah-sembuhkan-covid-19-di-3-negara

https://setkab.go.id/rapat-terbatas-melalui-video-conference-mengenai-laporan-timgugus-tugas-covid-19-30-maret-2020-di-istana-kepresidenan-bogor-provinsi-jawabarat/

https://news.detik.com/berita/d-4949513/jokowi-beri-insentif-untuk-dokter-tenagamedis-ini-daftar-besarannya

https://www.thejakartapost.com/news/2020/02/27/indonesia-stock-index-plunges-tothree-year-low-amid-virus-fears.html

https://nasional.kompas.com/read/2020/03/25/08475041/wakil-ketua-dan-anggotaombudsman-positif-covid-19

https://www.bi.go.id/id/ruang-media/info-terbaru/Pages/Perkembangan-IndikatorStabilitas-Nilai-Rupiah-27032020.aspx

https:/ / finance.detik.com/berita-ekonomi-bisnis/d-4956158/imf-nyatakan-pandemicorona-berubah-jadi-krisis-ekonomi-global 
http://covid 19.bnpb.go.id/

https://finance.detik.com/moneter/d-4957 146/ojk-minta-debitur-tak-serbu-leasing-ataubank-untuk-libur-cicilan

https://www.msn.com/id-id/berita/nasional/doni-monardo-corona-diprediksi-27300kasus-akhir-april-puncaknya-juni/ar-BB124jiU?ocid=spartandhp

https://news.detik.com/berita/d-4953745/negara-lockdown-gegara-corona-makinbanyak-ini-daftarnya/4

https://www.covid 19.go.id/situasi-virus-corona/

https://www.covid 19.go.id/2020/04/15/perlindungan-umkm-guna-menjagaproduktivitas-di-tengah-pandemik-covid-19/

https://www.presidenri.go.id/siaran-pers/

https://edition.cnn.com/2020/04/16/health/coronavirus-remdesivir-trial/index.html

https://www.dkv.global/risk-ranking 